\title{
Categorizing and Fixing Variables on Entrepreneurial Intention through Qualitative Research
}

\author{
Muhammad Amsal. S. ${ }^{1}$, Dileep Kumar, M. ${ }^{1} \&$ Subramaniam Sri Ramalu ${ }^{1}$ \\ ${ }^{1}$ Othman Yeop Abdullah Graduate School of Business, Universiti Utara Malaysia, Malaysia \\ Correspondence: Muhammad Amsal. S., Othman Yeop Abdullah Graduate School of Business, Universiti Utara \\ Malaysia, Malaysia. E-mail: amsalsahban@yahoo.com
}

Received: June 9, 2013 Accepted: July 28, 2014 Online Published: September 29, 2014

doi:10.5539/ass.v10n19p45 URL: http://dx.doi.org/10.5539/ass.v10n19p45

\begin{abstract}
Many policies and regulations have been made by Indonesian Government to enhance the quality of graduates in higher education. Numerous programs have been launched to build the mentality and business awareness of university students such as National Science Fair (PIMNAS), Student Entrepreneur Program (PMW), Student Creativity Program (PKM), Business Incubation Program and many other programs that can enhance the propensity of the students to start up a business. However, there are only $17 \%$ of the graduates who are willing to become entrepreneurs each year. This indicates that students have a lack of intentions to become entrepreneurs. However, there is less research and literature to support the argument that the students do not have entrepreneurial intention. In order to explore the entrepreneurial intention among the Indonesian students graduating universities and business schools from a qualitative study was conducted. The methodology used to develop an appropriate variable for entrepreneurial intention is focused group discussion (FGD), case analysis, interviews and Delphi technique measures the student's entrepreneurial intention. There are 20 experts were willing to take part in this study and the study identified 4 factors that eventually suit the student desire to deal with entrepreneurship. This study gives a valuable contribution to the higher education institutions, to orient the students to become entrepreneurs through right grooming by ensuring better entrepreneurship program as well as the curriculum.
\end{abstract}

Keywords: entrepreneurship, entrepreneurial intention, students, entrepreneurial incubation center

\section{Introduction}

Entrepreneurial intentions lately began to receive attention for study because it is believed that a behavioral intention is proven to be a reflection of actual behavior (Krueger, 1993).Attitudes, behaviors, and interests of students towards entrepreneurship are influenced by consideration of the various aspects of the career choice as an entrepreneur. Consideration of the career options may vary depending on the preference of the risks that they will be responsible later. Students who have less courage to take risks (risk averter) tend to choose to be an employee of the private sector, civil servants, or employees of State Owned Enterprises (SOEs) as their career option, while for those students who are able to take risky action (risk takers) by leaving their comfort zone will tend to take up entrepreneurship as a career option (Lestari \& Wijaya, 2012).

However, Indonesia relies more on the entrepreneurs compared with the civil servants or employee because a large number of entrepreneurs can enhance the economic growth and development which are still considered very low in Indonesia.Meanwhile, only $17 \%$ of the graduates who are willing to become entrepreneurs each year, this indicates that students have less intention to become entrepreneurs (Amrullah, 2012; Fitriati, 2012; Rahmawati, Suwarto, \& Endarwati, 2010). Other studies revealed that Indonesia only has 570.339 entrepreneurs or $0.24 \%$ this year (Arcom, 2013). This percentage still very low if we compare to Malaysia and Singapore and China. In order for a country to be considered as developed, the country must have at least $2 \%$ of entrepreneurs from its population (Mc Celland, cited in Rochmah, 2013). It is not few graduates recently wanting to be an employee, the result of many surveys and observations with the students revealed that there are around $75 \%$ want to apply for the job, in other words they want to be employees and only around 4\% who answered that they would like to deal with entrepreneurship and the rest want to be employees (Brawijaya University, 2013). This result is in line with the study conducted in Spain. The study in Spain with the sample of 601 university students from Castilla district indicated that there is a high intention of the student to be an employee in both private or 
public companies, however, their intention to be entrepreneurs is low (León, Descals, \& Domínguez, 2007). This study analyzes the low intention among students to be an entrepreneur because a stimulation of entrepreneurship activities provided by the universities is still low.

\subsection{Issues Pertinent to Entrepreneurial Intention}

There are several factors that lead a student does not like entrepreneurship, including the majority of students prefer the safer way rather than facing challenges to entrepreneurship. Students mostly prefer a safe way to obtain income rather than facing challenge to be an entrepreneur (Putra, 2012). They are generally not willing to take a risk, especially in term of funds. Zain (2013) stated that that the higher the someone's education level, the lower the intention they have. From this study, it was revealed that only $6.14 \%$ of the graduates who want to take a part in entrepreneurship, while more than $20 \%$ of those who did not finish their study in elementary school are willing to be entrepreneurs. In addition to that, the data from the General Directorate of Youth and Education, National Education Department stated that from $75.3 \%$ of youth, $6.6 \%$ are from university graduates, and $82 \%$ from the amount of youth are working as an employee at public and private institution, while only $18 \%$ become entrepreneurs. Further, the advisor of the Minister of Cooperatives and SMEs, Drs. Sutarto announced that student's interest in entrepreneurship remains low. In 2011, over 10,000 students attended the student entrepreneurship programs, but it's only 5,000 students who make it happen and of the 4.8 million students, only 7.4 percent of students who are interested in entrepreneurship (Sutarto, 2012). Students are generally not willing to take risks, especially in terms of the use of funds. Basically, those who have the financial ability to spend their money prefer to spend their money in consumptive way. While they did not dare to spend money on activities which involve risks or entrepreneurial activity (Sulistyorini, 2013).

This phenomenon indicate that the level of knowledge and awareness of university graduates about the importance of entrepreneurship is still very low that lead to a lower interest of entrepreneurship of the students (Astuti, 2013). Astuti (2013)also states that the students in senior high school located in Bandung, Indonesia are not even being embedded in a mindset of entrepreneurship, resulting they choose to become an employee instead of an entrepreneur. Referring to that, we can easily measure their mentality and business awareness and predict that they are likely to become job seekers once they pass out from universities. Lack of interest in entrepreneurship mostly because starting a business is too heavy compared to work in a company or other formal employment. In addition, the number of competitors in the business world also makes the graduates of vocational school feel less confident to open a business. Lack of competence of the students also makes students less motivated, resulting they have no courage to take the risk to open a new business. This is because of there is a shadow of failure that will be faced in the future (Mustikawati \& Bachtiar, 2008).

Entrepreneurial world is basically a fairly rational choice in a situation and condition that are difficult to be relied upon, as well as the difficulty of finding a job. However, the entrepreneurial world until now has not become a demanded job field to young people. Even though there are many entrepreneurship programs have been launched to grow the entrepreneurial spirit and business awareness among Indonesian society, the people are unlikely interested in entrepreneurship. This statement is also supported by Ramadhan (2012), he found that the awareness of society and university students in Indonesia toward entrepreneurship spirit is still relatively low where their mindset is still embedded an employee spirit, particularly for the university graduates. Most of the graduates are not only expecting to become a civil servant, but also are having lazy nature (do want to work), not yet ready for use, poor mental attitude, not confident, etc. Such characters are derived from a life that full of doubt, without having a firm orientation, the mentality is not good, no self-confidence, no discipline, and a mentality that ignores the responsibility. It is due to the difficulty to alter the perception of community that being an entrepreneur is a lucrative and noble job because it could open job vacancies for other people (Ifham \& Helmi, 2002). On the other hand, the government does not totally encourage the emergence of new entrepreneurs; they are only shaping students to be employees. In other words, they only prepare the graduates to work in the company rather than being entrepreneurs who are able to reduce the number of unemployment, crime and are able to enhance the economy of a nation (Mulyana, 2013).

\section{Literature Review}

There are quite a lot definitions of entrepreneurship that are explained by previous researchers. For instance, Cole (1959) views the entrepreneurship as an activity that aims to initiate and establish trading that orientate to profit. While Kao (1995) declared the entrepreneurship as the process of creating something creatively and differently (innovation) which aims to acquire wealth for individuals and increase the value-added in society.

Knight (1921)stated that entrepreneurship as an individual's ability to deal with risky activity and uncertainty in order to obtain a profit. As stated by Sexton and Bowman-Upton (1991), entrepreneurship as a process of 
recognizing the opportunities with certainty that exist in the market, preparing resources to achieve the goals that ultimately the necessity of resources will be exploited in order to achieve personal gain in the long term. Meanwhile, according to Schumpeter (1934) argued that entrepreneurship aims to run new combinations such as creating a new product or service, obtaining new sources of raw materials, targeting new markets, and new organizational formation.

Entrepreneurship is considered very effective to reduce the problem of unemployment. Someone who has the entrepreneurial skills will be able to compete with others, including overseas labor strike in the midst of globalization. Entrepreneurship is one of the areas of work that could be an option for a person when he decided to enter the workforce. Entrepreneurship is a word often used to translate the word entrepreneurship as a process of creating something different with value devote the necessary time and effort, being willing to bear the financial risk, psychological, and social as well as generate financial rewards, personal satisfaction, and freedom (Hisrich \& Peters, 1998).

On the other hand, intention is an attribute that relatively stay on individual its impact is very big toward one's activity because the individual will perform something that he is intended to, while, without the intention, the individual would not perform anything. As explained by Mustikawati and Bachtiar the interest is an intrinsic power to encourage, influence or cause the individual concerned or interested in something outside themselves consciously accompanied by pleasure. The ultimate purpose of intentions research is the prediction of behavior.

Entrepreneurial desire can be interpreted as the initial step of the establishment procedure of business that is generally long term (Lee \& Wong, 2004). As discoursed by Krueger (1993), entrepreneurial intention reflects the one's commitment to start a new venture and is a central issue that need to consider in understanding the entrepreneurial process of new business establishment. Entrepreneurial intentions lately began to receive attention for study because it is believed that a behavioral intention is proven to be a reflection of the actual behavior.

A person with the intention to start a business will have the readiness and better progress in the effort to run than someone without intense to start a business. As stated by Krueger (1993), the intention has been proven to be the best antecedent for one's entrepreneurial behavior. Referring to that, we can simply use the intention as a predictor to understand who will definitely intent to be entrepreneurs (Choo \& Wong, 2006). Lee and Wong (2004) affirmed that the entrepreneurial intention is the first step of the process of establishment of a business that is generally long term.

\subsection{Theory of Planned Behavior Model}

One of the entrepreneurial intention models is a theory of Planned Behavior (Ajzen, 1991) and has been heavily used in some research literature given its ability to reflect a person's behavior and interest in doing a business. Based on the one's convictions, attitudes, and interests will certainly affect the behavior of the individual. In the perspective of entrepreneurship, this means that the trust of being an entrepreneur and a person's attitude to entrepreneurship can be a strong platform for the individual to build a new business.

The theory of Planned Behavior which is derived from the Theory of Reasoned Action (Fishbein \& Ajzen, 1975), where the TRA states that a person's behavioral interests may be shaped by attitudes toward the behavior and subjective norms of the individual (for example, the attitude can be influenced by others such as parents, spouse, idol and so on) (Mcstay, 2008). Thus, either the attitude or the subjective norm is affected by the evaluation which means a motivation belief which is formed through one's environment. For more details, Theory of Reasoned Action can be seen in Figure 1 below:

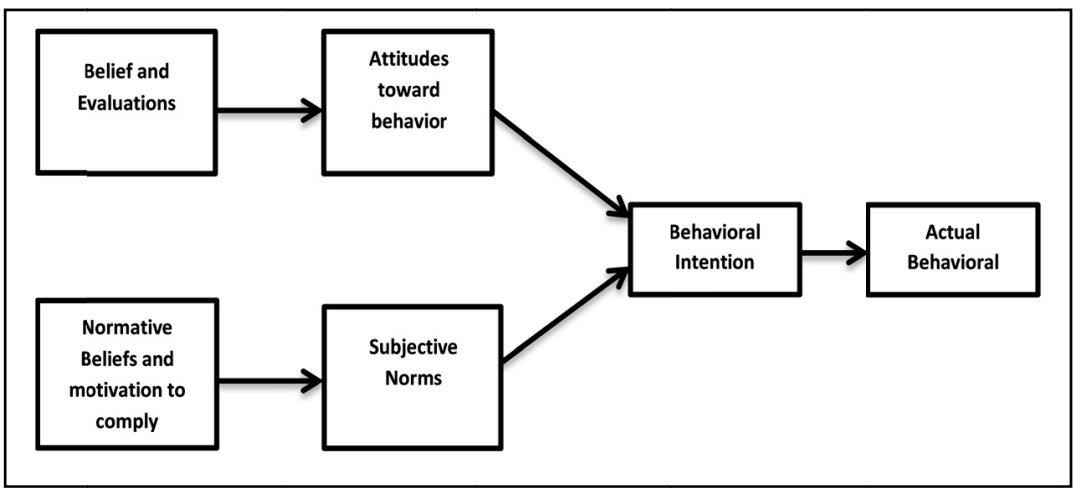

Figure 1. The theory of reasoned action (Source: Fishbein \& Ajzen, 1975, cited in McStay, 2008) 
On the other hand, Theory of Planned Behavior assumes that human behavior is largely derived from the interest of the individual to display such behavior and their ability to decide or make a decision to do something (their own willing). This theory explains that a person's interest depends on three elements : (1) a person's attitude toward the behavior (do I desire to perform it ?), (2) subjective norm (do other people wish me to execute it ?), And (3) perceived behavioral control ( do I think I am capable of doing it and have the resources to perform it ?). Basically, the third element is the supplementary factor of the original model - Reasoned Action Theory. Person's attitude toward the behavior and subjective norms were also considering motivational factors that can affect behavior. In contrast, the third element (perceived behavioral control) is considered as non-motivational factors that can influence behavior. If these three factors combined, then those would reflect the actual behavior of individuals and generally can be used to predict a person's interest or behavior (Ajzen, 1991, in McStay, 2008).

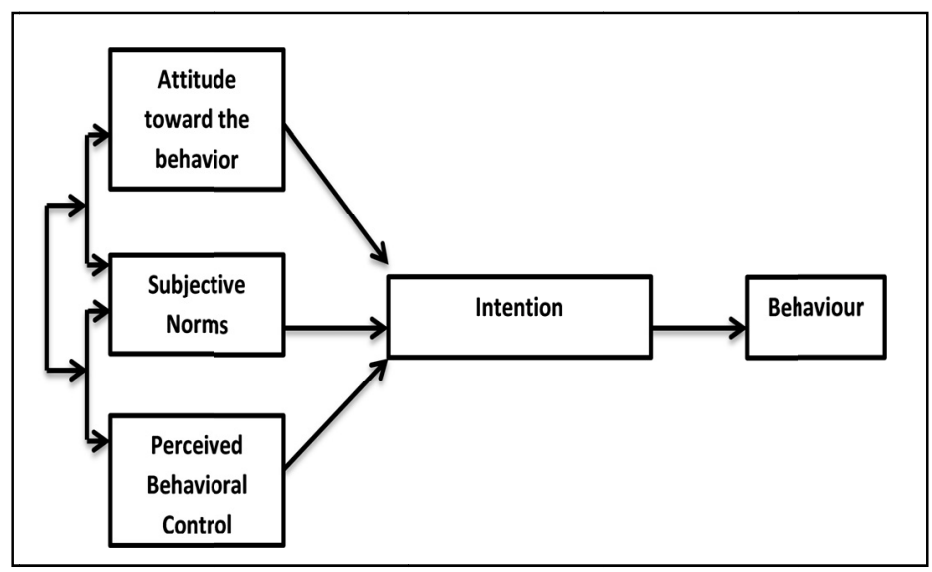

Figure 2. The theory of planned behavior by Ajzen (1991) cited in McStay (2008)

he figure above explains that attitude toward behavior, subjective norms, and perceived behavioral control can affect a person's intention while intention can affect a person's behavior. Despite the absence of attitude and subjective norm, but if it is supported by perceived behavioral control is good, then it will also be able to influence the behavior of a person to make choices and take decisions. While between the attitude, subjective norms, and perceived behavioral control can affect to each other. Then, Gurbuz and Aykol (2008) developed this model by taking several indicators to measure entrepreneurial intention which constitutes security and workload, avoid responsibility, economic opportunity and challenge, autonomy, authority, self-realization, participation, social environment and career, perceived behavioral control.

\subsection{Shapero-Krueger Model}

Today there are several models of entrepreneurial interest developed by some experts like entrepreneurial interest model developed by Shapero and Sokol,1982. The model of entrepreneurial intention (Shapero \& Sokol, 1982) is known as the "entrepreneurial event formation" which is considering a change in the flow of life and its effect on the individual's perception and desire for a new formation. This model assumes that the change of life will affect changes in a person's interest in entrepreneurship and subsequent behavior. The move will lead to two things whether negative or positive, negative for instance, there is a loss of a job and so on, while the positive things such as obtaining financial support. Propensity to become entrepreneurs and create a new venture highly rely on one's perception of desirability such as "do I desire to execute it?" And feasibility such as ' do I have the resources to perform it? Guerrero, et al., (2008) in Gurbuz and Aykol (2008) also stated the same thing where there are two related literatures have similarities about the factors that influence the behavior of a person to perform a certain activity. The approaches are: Shapero approach which is known as Model Shapero Entrepreneurial Event (SEE) and the Model of TPB (Theory of Planned Behavior)

As discoursed by Shapero there are two perceptions that influence a person's behavioral intention, namely; 1) perceived desirability that refers to the perception of someone for behavior that is attractive and desirable, 2) perceived feasibility that constitutes one's perception of her ability to perform the desired behavior. Krueger(2000)then inserts the three predictors as determination directly or indirectly toward the intensity of self-employed like propensity to act, which indicate a motivation in a person to behave. The intensity varies for each individual so that it is widely known as Shapero-Krueger Model [See fig. 3](Krueger et al., 2000). 


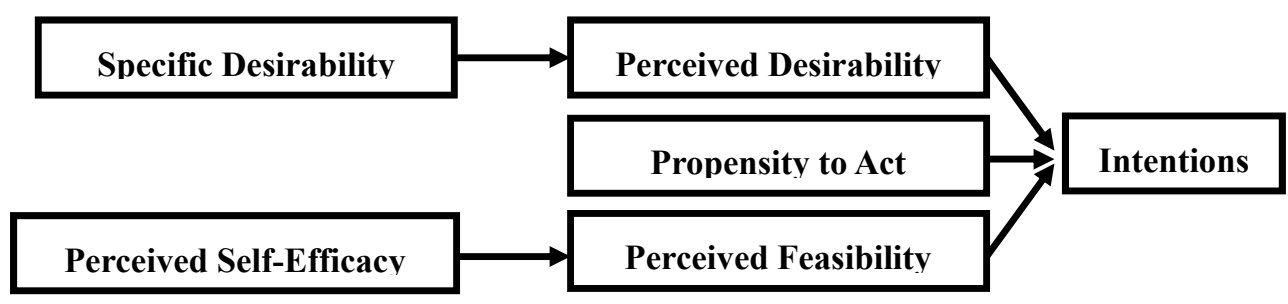

Figure 3. Shapero-Krueger model (Source: Krueger, Reilly, \& Carsrud, 2000)

To determine on how entrepreneurial goals are evident in 'Entrepreneurial Event Formation' Shapero and Sokol looked at life path changes and their influence on the individual's perceptions of both desirability and availability leading to new business implementation. This framework considers that substantial life changes (displacement) precipitate a change in entrepreneurial desire and subsequent character. Displacement can happen in a negative form (e.g. Divorce, loss a job) or a positive form (financial support, good business partner). The desire to become an entrepreneur and make new business (an entrepreneurial happens), therefore, rely on one's perceptions of both desirability and feasibility with regard to that activity (Mcstay, 2008).

A good character is determined by the choice an individual makes for a given situation (in this situation to this decision maker) plus some "propensity to act" (Without which significant action may not be taken). "Credibility" requires a behavior be seen as both desirable and feasible. Entrepreneurial events thus require the potential to start a business (credibility and propensity to act) to exist before the displacement and a propensity to act afterwards (Shapero \& Sokol, 1982).

\subsection{Perceptions of Desirability of Entrepreneurship}

As stated by Shapero and Sokol, the entrepreneurial event is a product of an individual's view regarding entrepreneurial desire affected by their own personal attitudes, beliefs and way of thinking as a result of their unique social environment (eg. Family, peer groups, educational and professional influences). In other words, an individual needs to observe the self-employment as desirable action before the self-employment intentions will be formed (Mcstay, 2008). Perceived desirability also refers to the personal attractiveness of starting a business and it closely knit with Ajzen's attitude and the subjective norm variables (Krueger et al., 2000). Bird (1988) cited in McStay (2008) considered desirability to be formed through 'intuitive thinking' in the process of intentions. Giagtzi (2013) stated that the desirability can be influenced by the normative environment (social norms) and cultural factors. Perceived desirability of entrepreneurship is an affective attitudinal judgment (an emotive response) and entrepreneurs use such judgment to make decisions on whether or not to act (Mitchell et al., 2002). It is possible that university student possessing desirability for self-employment will consider self-employment as a viable career option following their graduation from university education. The desire of pursuing entrepreneurial action is a function of motivation and it is reasonable to assume that both participation in entrepreneurship education and previous entrepreneurial experience would be motivating factors for one to consider self-employment as a career option (McMullen \& Shepherd, 2006).

Perception of desirability refers to one's entrepreneurial attitude who wants a better effort and always evaluates the cost and benefit of entrepreneurial activity results. Therefore, the higher the desirability and feasibility, the stronger the one's intention to perform an entrepreneurial activity (Hisrich, 2008 in Astuti, 2009). On the desirability side, is generally accepted that the students, at this moment of their life, have more positive intrinsic motivations (to be independent from the economic point of view to create something own or to create personal patrimony in the long term period) the necessities (to find a good job and monetary retributions to find a status in the society). Also, other influence is the normative environment (social norms) that exists in each region. It is noted that there are favorable attitudes towards entrepreneurship and specifically a positive perception of the entrepreneur as a profession (Guerrero, Rialp, \& Urbano, 2006).

Perceived desirability is defined as "the degree to which starting a new business is perceived as a desirable career option". The three perceived desirability cognitive script element measures in the Krueger scale are: I would love doing it; I would not be tense at all; I would be very enthused (Dodd, Komselis, \& Hassid, 2009).

Perceived desirability reflected the personal attractiveness of starting a business and very closely relates to Ajzen's attitude and subjective norm variables (Krueger et al., 2000). This is impacted by social background, 
which is comprised of broader cultural influences, as well as family, friends, and personal exposure to entrepreneurship. This history results in a pre-loaded perspective about this path or choice, positive or negative (Kuehn, 2008).

\subsection{Feasibility Perception of Entrepreneurship}

According to Shapero's Entrepreneurial Event (Shapero \& Sokol, 1982), the view of entrepreneurship feasibility is based on one's perception towards available resources (e.g. Knowledge, financial support, and Colleagues). Krueger et al (2000) stated that perceived feasibility is the degree to which the individual feels personally capable of starting a business. Based on the Shapero-Krueger model, entrepreneurial self-efficacy is a suitable alternative for perceived feasibility. Further, McMullen and Shepherd (2006) asserted that belief in the ability to pursue entrepreneurial action (perceived feasibility) is a function of entrepreneurial understanding.

McStay (2008) introduced Perceived entrepreneurial self-efficacy which is a precise form of self-efficacy. It describes an individual's views of his own capability in doing a business. There are some item-scales addressed three different roles regarding self-employment. The three roles include opportunity recognition and innovation; business, financial and human resource management, and coping with risk and unexpected challenges. Efficacy for each task was assessed with five items. The example of statements from each role such as: opportunity recognition and innovation ("I believe I can create products or services that fulfill customers' unmet needs" and "I believe I can think productively in doing a business"); Management Skills ("I believe I can create and achieve goals as well as objective in running a new business venture" ; "I believe I can identify and build a management team to develop a business"); coping with risk and unexpected challenges ("I believe I can tolerate unexpected changes in business conditions").

Self-efficacy, which measures feasibility, also can be influenced by obstacles, personal capacities/skills, and confidence in their ability to perform entrepreneurial tasks, perceived availability needed to create a business and the regulatory environment (Gasse \& Tremblay, 2011). In a similar train of thought, Drnovsek and Erikson (2005) in Giagtzi (2013) confirm that the individual's control is dependent on the availability of opportunities, resources, as well as prior experiences. Bandura (1977) identified the four main sources of self-efficacy beliefs: enactive mastery (prior experiences), vicarious experiences (observing others' performances), social persuasions (making people believe they are capable of being successful) and physiological stimulation.

Perception feasibility reflects the level or degree or personal competence to start a business as felt by the person. This perception is viewed as related to Ajzen's behavioral control variable in that both of these focus on a person's assessment of his/her ability to manage the business start up process successfully. It is a measure of uncertainty, and uncertainty is the perception of controllability of a situation(Kuehn, 2008).

Generally, relating to the idea of evaluating opportunity it is all about predicting the future, particularly with the integration of wealth resources (Haynie, Shepherd, \& McMullen, 2009). Another explanation of the world opportunity has been introduced. Majorly comprises of three central components (Baron, 2006)such as potential economic value (ie. The capacity to generate profit), newness (ie. some product, service or technology that have not happened before), and perceived desirability (eg moral and legal acceptability of the new product of service in society).

According to Gundry \& Kickul (2007), in order to examine the opportunity, there are quite a lot questions occurred such as :

1. The resources available to the entrepreneur and the management team, including the equity and debt sources of capital that are available and accessible, additional assistance from people with expertise needed by the firm, and the technology required to support the idea. What relationships can the entrepreneur or team relies on to acquire the necessary resources?

2. The knowledge and information demonstrated by the entrepreneur, including knowledge of the concept of new business, the industry, and market research. In addition, for the new venture to be a success, what sort of customer needs that should be identified? Facts relating to the competitors? Placing a priority for the costumer demand? How can this vital idea be attained?

3. The idea's ability to generate revenue. How great the potential to sell something that is will generate actual revenues? One of the mistakes would be entrepreneurs make is to assume that everyone will love the idea and that people will be standing in line to buy it, once the business opens. To what degree can the entrepreneur manage and contain the costs while maximizing returns? 


\subsection{The Propensity to Act}

Shapero's idea on "propensity to act" is a personal disposition to act on one's decisions, hence demonstrating one's ability to do something ("I will do it").

It is hard to predict useful knowledge plan on intention if there is a lack of propensity to act. Actually, propensity to act on an opportunity relies on consistent check on one's understanding an issue which is achieved by taking necessary action. Scientifically, we are required to obtain a measure that closely knit to start and to understand the goal to channel human behavior depending on mishap. Relating to the influence of age on entrepreneurial propensity, they arise other great consequences. Firstly, the acquisition of human and financial capital will give rise thorough one's life, which would likely commence with immediate effect. Secondly, an appreciable increase in private and job related commitment with a shorter lifespan will decrease to the propensity to venture depending on the risk and long-term oriented investment for a start-up.

Propensity means an inclination to do something, or an attitude of mind especially one that favors one alternative over others, or a disposition to behave in a certain way. Propensity to act reflects a person's predisposition to act on a decision. Shapero and Sokol's model presupposes an individual's willingness to act on choices, but is explicitly developed by subsequent authors testing their model. This variable has been argued elsewhere to be similar to risk-taking propensity and tolerance of ambiguity, defined as a person's willingness to take action when outcomes are not known (Shane, 2003 cited in Kuehn, 2008). As far as the measure of this variable, some have favored internal locus of control as an orientation to control life events, as has learned optimism (Krueger, et al., 2000).

The possibility of venturing into thinking positive with the aim of getting an acknowledgement attach to be successful that is needed by an individual before he will give himself to the causes related to a failure, the alternative, the other means are getting little gains with little causes compared to the introduced condition (Hyrsky \& Tuunanen, 1999). In addition, personal attitude predominantly affect entrepreneurial intention. Personal attitude represents an individual's belief about the value (value) which according to them is valuable and want to achieve in the future. Such value becomes one's motive to pursue the profession of entrepreneurship. A number of motives are believed by researchers can be a driving factor to pursue one's profession such as freedom to act and make decisions, higher income, self-actualization, and self-reliance. Those motives will motivate students to pursue a profession as an entrepreneur in the future (Lestari \& Wijaya, 2012).In addition to those 3 dimensions, there is another thing that we need to take into account which is the self-realization dimension.

\subsection{Self Realization-Participation}

Self-discovery is a way of appreciating one's potential by manifesting one's true ability. The sun covered by thick cloud is a good way of comparing oneself with others of similar character which is not visible in oneself in the day to day activity. the separation of thinking too much about oneself, hidden traits with its psychosomatic character making a room for psyche's energy to affect one's world as it is, free of any assumptions. According to Alsos and Isaksen (2012) there are four statements were included in the self-realization dimension: (i) self-realization, (ii) realize one's dreams, (iii) to have an interesting job, and (iv) to create something. Gurbuz and Aykol (2008) describe self-realization as participate in the whole process. Gurbuz and Aykol (2008) also used some attributes to measure self-realization and participation of the individuals, they are: (1) to create something, (ii) to take advantage of your creative needs, (iii) to follow work tasks from a to $z$, (iv) participate in the whole process. Self-realization also refers to the act of achieving the full development of your abilities and talents. Self-realization described reasons involved with pursuing self-directed goals (Carter, Gartner, \& Greene, 2002). Carter, et.al (2002) also used four items to represent the pursuit of self-realization that can motivate individuals to become entrepreneurs (i) fulfill a personal vision; (ii) to lead and motivate others; (iii) to have the power to greatly influence an organization; (iv) to challenge myself.

\section{Research Methodology}

This particular study followed Delphi technique as it design of method to explore categories and factors related to entrepreneurial intention issues in various universities. As it is known, the Delphi technique is one of the methods, which started its usage in 1950, in order to get consensuses, which is linked to real world knowledge coming through experiences on the area related to research topics. It is pointed out by Dalkey (1972) that the consensus on decisions which is coming from heads is better than one, or... $\mathrm{n}$ heads are better than one. Delphi technique is considered as one of the effective communication process with the objective of making deep analysis base on deliberation on a specific problem in order to set the goal, undertake a probe into the policy or to make effective prediction on the occurrence of future events (Kumar, 2013). Basically the Delphi technique is 
conducted in the form of semi-structure interaction and interview. High concentration on the process is envisaged to ensure the rigorous.

During the middle of march to the middle of November 2013 Delphi process organized among the resources people carefully selected based on the expertise knit with entrepreneurial intention and interviews whereby.

Interview by phone is performed to collect and process information from the respondents. As many as 42 experts from industries and academy were acknowledged and approached by email or telephone. They were invited to take part in the study. All the clarifications related to the purpose of the study were completed by researcher. However, from 31 respondents were being interacted and communicated, there are only 20 respondents shown their keenness to contribute in this research project. Finally, 20 participants were interviewed by phone and through email. The conversations are taped recorded, and manually analyzed. The procedural steps in adopting the Delphi technique were as follows.

\subsection{Expert Panel Identification}

The group of professional was completed from specialists having high comprehension and proficiency in entrepreneurial intention. They are closely linked with industries such as consultants, business owners, top level managers, entrepreneurs, professors, researchers as well as academicians. The expertised areas of the choosen expert members include 15 male $(75 \%)$ and 5 female $(25 \%)$. These dynamic panel of experts are knowledgeable and familiar to give related opinions and an acceptable notion of the entrepreneurial intention concept.

\subsection{Rounds}

\subsubsection{Round 1}

In the initial round, the Delphi process essentially begins with an open-ended questionnaire. The open-ended questionnaire serves as the cornerstone of soliciting specific information about a content area from the Delphi subjects (Custer, Scarcella, \& Stewart, 1999).

The questions:

1. How do you define entrepreneurial intention?

2. Which are the major factors, in general closely related to entrepreneurial intention?

3. Contextualizing the topic to the Indonesian scenario, which are the major factors, closely related to entrepreneurial intention in Indonesia?

\subsubsection{Round 2}

The second round concentrate into categories and the items which are more closed to the concept entrepreneurial intention. Followed by the procedure the Delphi members received the second questionnaire and accordingly they were required to rate or rank order the items in order to establish first level preferences among item incorporated into. In this stage, based on the decision and deliberation, agreement and disagreement on the items consider in relation to entrepreneurial intention were make. Care should be taken that, the number on Delphi iteration should be based on how far consensuses have been arrived at effectively on the concept entrepreneurial intention in the study. The process identifies 191 categories, which are having items with high and low proximity of entrepreneurial intention identified. Rating process further acknowledged in the groupings and items identified.

\subsubsection{Round 3}

In the third round, each Delphi panelist receives a number of questionnaires that include the categories and items ratings, summarized by the investigators in the previous round and are asked to revise his/her judgments or "to specify the reasons for remaining outside the consensus" (Pfeiffer, 1968). This round gives Delphi panelists an opportunity to make further clarifications of both the information and their judgments about the relative importance of the categories and items. Second level screening of the 191 categories which were having a high and low influence on entrepreneurial intention identified with corresponding items. The process further identified 60 categories, which are having high and low proximity of the entrepreneurial intention identified. Classification of the items in 60 categories of 4 factors was being made with appropriate loaded items. Thematic presentation and the categorization of the items were done.

\subsubsection{Round 4}

This round is the last round in which the researchers tried to eliminate the minority opinion in order to capture the maximum level of consensus based on their rating on the categories and items which related to entrepreneurial intention. Crosschecking of this categories and items were thoroughly make and the suitability clearly ascertained for fixing up the categories and items related the factor entrepreneurial intention. During 
fourth level, screening of the 45 categories of 4 factors which were having items with high and moderately high proximity of entrepreneurial intention identified. Sought the expert opinion on the appropriateness of the core factors selected for the study.

\section{Results}

Table 1. Delphi table on Entrepreneurial Intention

\begin{tabular}{|c|c|c|c|c|c|}
\hline No & Factors & Categories & $\begin{array}{l}\text { No. of } \\
\text { items }\end{array}$ & $\begin{array}{c}\text { No. of } \\
\text { Experts } \\
(\mathrm{N}=20) \\
\end{array}$ & $\begin{array}{c}\% \text { of } \\
\text { Experts }\end{array}$ \\
\hline \multirow{5}{*}{1} & \multirow{5}{*}{$\begin{array}{l}\text { Perceived } \\
\text { Desirability }\end{array}$} & Intention to be self-employed. & 1 & 17 & 85 \\
\hline & & Personal attractiveness of starting a business. & 2 & 18 & 90 \\
\hline & & Intuitive thinking. & 2 & 15 & 75 \\
\hline & & Using attitudinal judgment. & 3 & 15 & 75 \\
\hline & & The desire for Entrepreneurial action. & 2 & 17 & 85 \\
\hline \multirow{21}{*}{2} & \multirow{21}{*}{$\begin{array}{l}\text { Perceived } \\
\text { Feasibility }\end{array}$} & Entrepreneurial attitude. & 2 & 17 & 85 \\
\hline & & Positive intrinsic motivation. & 3 & 18 & 90 \\
\hline & & Positive perception. & 2 & 17 & 85 \\
\hline & & Perceived desirable career option. & 2 & 18 & 90 \\
\hline & & Availability of knowledge and information. & 2 & 17 & 85 \\
\hline & & Availability of financial support. & 2 & 17 & 85 \\
\hline & & Availability of partners. & 2 & 16 & 80 \\
\hline & & Capable of starting a business. & 2 & 15 & 75 \\
\hline & & Having strong self-efficacy. & 2 & 17 & 85 \\
\hline & & Availability and accessibility of resources. & 2 & 17 & 85 \\
\hline & & Ability to pursue entrepreneurial action. & 3 & 16 & 80 \\
\hline & & Ability to create products. & 4 & 16 & 80 \\
\hline & & Ability to cope with risk. & 2 & 15 & 75 \\
\hline & & Creative thinking. & 2 & 16 & 80 \\
\hline & & Envisioning the future. & 2 & 16 & 80 \\
\hline & & Confidence in performing entrepreneurial tasks. & 3 & 17 & 85 \\
\hline & & Prior experience. & 2 & 15 & 75 \\
\hline & & Observing other's performance. & 3 & 15 & 75 \\
\hline & & Ability to convince others. & 3 & 16 & 80 \\
\hline & & Transforming the changes in technology. & 2 & 17 & 85 \\
\hline & & Personal Competence & 2 & 15 & 75 \\
\hline \multirow{10}{*}{3} & \multirow{10}{*}{$\begin{array}{l}\text { Self } \\
\text { Realization- } \\
\text { Participation }\end{array}$} & The idea's ability to generate actual revenue. & 2 & 16 & 80 \\
\hline & & Participation in the whole process. & 3 & 18 & 90 \\
\hline & & Fulfill a personal vision. & 2 & 18 & 90 \\
\hline & & Lead and motivate others. & 3 & 17 & 85 \\
\hline & & The power to greatly influence an organization. & 2 & 17 & 85 \\
\hline & & Taking a self-challenge. & 3 & 18 & 90 \\
\hline & & Creating something new. & 3 & 17 & 85 \\
\hline & & Taking advantage of one's creative needs. & 3 & 17 & 85 \\
\hline & & Following work tasks from a to $\mathrm{z}$. & 2 & 16 & 80 \\
\hline & & Reason with self-directed goals. & 2 & 15 & 75 \\
\hline \multirow{7}{*}{4} & \multirow{7}{*}{$\begin{array}{l}\text { Propensity } \\
\text { to act }\end{array}$} & Disposition to behave in certain ways. & 2 & 15 & 75 \\
\hline & & Person's predisposition to act on a decision. & 2 & 17 & 85 \\
\hline & & Desire to gain control by taking action. & 2 & 16 & 80 \\
\hline & & Propensity to venture risky investment of a startup. & 3 & 18 & 90 \\
\hline & & The inclination to do something. & 2 & 17 & 85 \\
\hline & & Willingness to act on choices. & 2 & 15 & 75 \\
\hline & & Willingness to take action on certainty. & 3 & 18 & 90 \\
\hline
\end{tabular}


The first factor measured for the study was Perceived Desirability. The result point out that the experts identified 19 items which come under 9 categories of perceived desirability. The table showed that personal attractiveness of starting a business $(90 \%)$, perceive starting a new business is a desirable career option $(90 \%)$ and having strong positive intrinsic motivation $(90 \%)$ as the prominent factors which closely knit with an entrepreneurial intention towards young students. The experts also identified forming the intention to be self-employed (85\%), the desire of pursuing entrepreneurial action ( $85 \%$ ), one's entrepreneurial attitude who wants a better effort (85\%) and positive perception on entrepreneur $(85 \%)$ as the second most important factors that closely describe the entrepreneurial intention, followed with intuitive thinking in the intentions process and using attitudinal judgment to make a decision that constituted $75 \%$ of the experts' consensus. The young wards need to have knowledge of these categories of entrepreneurial intention.

The second factor considered for the study was the perceived feasibility in accordance with entrepreneurial intention. The professionals identified 46 items. The factor perceived feasibility consists of 20 categories. Major factors identified by the researcher such as availability of knowledge and information (85\%), availability of financial support $(85 \%)$, having strong self-efficacy $(85 \%)$, availability/accessibility of resources $(85 \%)$ and confidence in their ability to perform entrepreneurial tasks $(85 \%)$ and linking and transforming the changes in technology $(85 \%)$ in relation to the theme of entrepreneurial intention. Other factors like availability of partners $(80 \%)$, ability to pursue entrepreneurial action $(80 \%)$, ability to create products that fulfill customers' unmet (80\%), having creative thinking in business $(80 \%)$, envisioning the future $(80 \%)$, ability to convince other $(80 \%)$ and legal acceptability of the new product $(80 \%)$ as well as the idea's ability to generate actual revenue $(80 \%)$ are the next key factors on entrepreneurial intention. The supplementary factors identified by the expert include the capability of starting a business (75\%), ability to cope with risk and unexpected challenges $(75 \%)$, having prior experience $(75 \%)$, observing other's performance $(75 \%)$, the level of personal competence $(75 \%)$ and the self-achievement to start up business $(75 \%)$.

The third factor that correlated to entrepreneurial intention was the Self Realization-Participation. The experts acknowledged 23 items under 9 the categories of the major factor Self realization-participation in relation to student's intention to start up a business. The experts pointed out major influential categories like participation in the whole process $(90 \%)$, fulfill a personal vision $(90 \%)$ and challenging own self $(90 \%)$ that are closely coupled to students' interest to involve in self employed. In addition to that, the study also pointed out categories like to lead and motivate others $(85 \%)$, to have the power to greatly influence an organization $(85 \%)$, creating something new (85\%), and taking advantage of one's creative needs $(85 \%)$, as categories in closely knit with entrepreneurial intention. In addition to the above factors, the experts also related the following work tasks from a to $\mathrm{z}(80 \%)$ of the students in their intention towards self-employed. The experts have given minor scoring one category like Reason involved with pursuing self-directed goal $(75 \%)$ also has close affinity with the entrepreneurial intention of university students.

The last factor identified by the expert is Propensity to act. The experts identified 16 items under 7 categories that closely link to the young entrepreneur's regarding the propensity to act. Among this factor, major categories identified by the expert include a propensity to venture upon the risky investment of a startup (90\%), and willingness to take action when outcomes are not known (90\%). Further, the study considers categories like a predisposition to act on a decision $(85 \%)$ and inclination to do something $(85 \%)$ as second prominent factors in relation to the propensity to act. They further pointed out other categories such as desire to gain control (80\%), disposition to behave (75\%), and a willingness to act on choices $(75 \%)$ as the categories that closely knit with the propensity to act. Younger students need to have orientation on these categories of entrepreneurial intention.

\section{Discussion}

This particular study on entrepreneurial intention was to identify and fix variables through Delphi technique. As we aware a lot of models are available to study entrepreneurial intention among students, newcomers, new entrepreneurs, etc. While, with specific reference to Indonesian context how far these models and antecedents correlate with the entrepreneurial intention among students was yet to be as certain. Hence a study was made for categorizing fixing variables on entrepreneurial intention among Indonesian students. In these particular studies, two major models which are available in Entrepreneurial Intention context is well integrated and further evaluated with expert opinion using the Delphi technique. The results of the Delphi technique indicate that the variables coming from these two models are well supported by the expert and further considered for understanding EI among students of Indonesia.

The first factor expert identified in this particular research was perceived desirability, this dimension further elaborated as a student keen intention to become self-employed high attractiveness of starting a business, 
intuitive thinking in the intention process, high judgemental attitude in decision making, attitude to put better effort, very high positive intrinsic motivation, seeing entrepreneurship as a desirable career option and finally there is a positive outlook toward becoming an entrepreneur. Among these categories, the most important factors the expert identified was the strong positive intrinsic motivation and the student keen aspiration to become an entrepreneur. This indicates that these students need to have a perceived desirability of forming an intention to be self-employed. These attitude totally different from a person who wants to become a government employee or engage in casual employment without taking any risk in life. Intuitive thinking was the most important aspect with support a student desire to become self-employed to see several ideas of the business, to understand how to make money and profit and select a career path with self-confidence and risk taking and high tolerance. In order to get the desirability, the students should have basically a personal attraction to face the challenges and business and step by step walk toward success in any ventures he might take in the future. By measuring all these categories in relation to major factors perceived desirability support in measuring students' entrepreneurial intention.

The second factor identified by the expert is perceived feasibility of a new ventures the students may take up soon after the completion of the course. In this context, the expert has categorized many aspects related to the feasibility of the project. In order to start the venture, a student need to have several information like starting a business, getting financial support, getting the right business partners, right entrepreneurial actions, level of personal competence, ability to convince the stakeholder, creative thinking, customer orientation, strong self-efficacy, market analysis and prior experience. The feasibility of a business lies with several factors like market orientation, customer orientation, raw material availability, prior experience in handling business, availability of finance, availability workers, knowledge about logistics and supply chain, etc. Lack of knowledge related to all these prominent entrepreneurial factors may lead to business failures. So the experts have the opinion that the students need to perceive adequate feasibility on related categories which are identified elsewhere that determine their intention to become entrepreneurs. These categories need to be explored with adequate number of items in order to measure students' intention to become an entrepreneur.

The third factors identified by the expert was self realization-participation. One of the most important aspect a student need to have in the learning and development process related to entrepreneurship is awareness about their self, abilities, vision of life and think differently from others. The students should not only ensure there on confidence in taking up the risk, facing the challenges, leading their personal vision with which they must lead them self and others all activities envision so far for the attainment of goal realization. The student need to have better participation in the whole process by leading and motivating others, challenging the present scenarios, following creative thinking, that support all activities from a to $\mathrm{z}$ reasoning and pursuing self-directed goals. By assessing these categories, the researchers would be able to measure students' attitude toward entrepreneurial intentions.

The last but not least factor identified by the expert include the students' propensity to act toward their goal to become an entrepreneur. In order to quantify their behavior, their disposition to act on entrepreneurial decision, they desire to gain control over the decision to become an entrepreneur, the propensity to venture upon risky investment, the strong inclination to do something by themselves rather than becoming a follower of the system, the decision to lead by choices than by chance and their strong inclination to choose a career as entrepreneur need to be measured. The measurement of all these categories would be able to assess whether the student will opt their career as an entrepreneur or their propensity to act as an entrepreneur.

Henceforth, these four factors and the respective categories like to perceive desirability, perceived feasibility, self realization-participation and the propensity to act toward entrepreneurship need to be measured to examine student's entrepreneurial intentions.

\section{Implication}

This particular study on entrepreneurial intention has the objective of identifying and fixing right variables to conduct and elaborate study on the student's and their ability to convert their desire to intentionally further becoming an entrepreneur. The study identified 4 entrepreneurial intention factors like perceived desirability, perceived feasibility, self realization-participation and propensity to act which are closely related to entrepreneurial intention among Indonesian student. The study having far reaching implication when customizing the variables, connecting to various models in the Indonesian context. Before adopting a model in its application on varied geographical location and stakeholders, care should be taken that these variables that were developed in the west may or may not have its suitability to the east. So, fixing up variables on a theme like entrepreneurial intention among Indonesian students that need to integrate variables from different authors like 
Ajzen (1991)Shapero and Krueger(1982) as well as Gurbuz and Aykol(2008). This particular research thus leads us to point out theoretical and managerial implications closely connected to its adaptability in the Indonesian context, by identifying the need of integrating models and variables from different authors on the same phenomena.

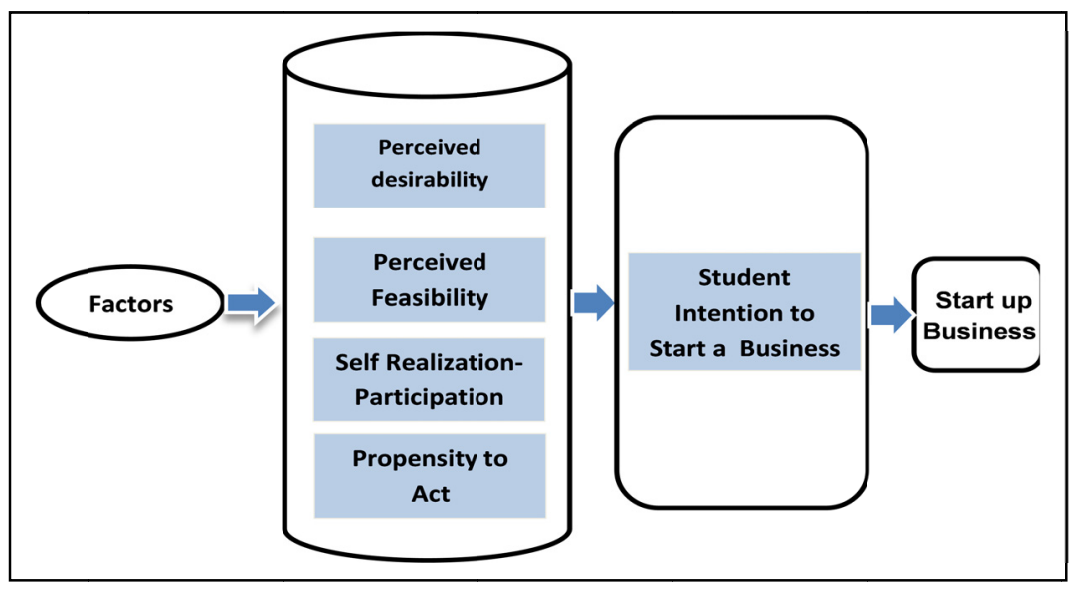

Figure 4. Model development

\section{Conclusion}

Several studies have been conducted to measure entrepreneurial intention among varied stakeholders. These studies have adopted single model and theoretical grounding to measure entrepreneurial intention among the stakeholders. Being different from the past studies, this particular study integrates 2 to 3 models available in entrepreneurial intention proposed by several research scholars to measure entrepreneurial intention among Indonesian student in universities and business schools. In order to integrate these models, this particular study employed delphi technique of qualitative research that runs through expert opinion in order to identify the factors, fix the categories belong to each factor and expose these categories and factor for extensive studies with the support of quantitative research. This study thus identifies 4 factors and 45 categories that support the researchers to have the extensive studies on Entrepreneurial Intention among Indonesian students.

\section{References}

Ajzen, I. (1991). The Theory of Planned Behavior. Organizational Behavior and Human Decision Processes, 50(2), 179-211. http://dx.doi.org/10.1016/0749-5978(91)90020-T

Alsos, G. A., \& Isaksen, E. J. (2012). Closing the gender gap? Entrepreneurial training and entrepreneurial intentions among male and female youth. In the 17th Nordic Conference on Small Business Research. Helsinski: Bodø Graduate School of Business at the University of Nordland.

Amrullah, A. (2012). Mayoritas Lulusan Perguruan Tinggi tak Tertarik Jadi Wirausahawan, Kok Bisa? Retrieved from http://www.republika.co.id/berita/nasional/umum/12/03/03/m0aira-mayoritas-lulusan-perguruan-tinggi -tak-tertarik-jadi-wirausahawan-kok-bisa

Arcom. (2013). Sekjen Kemenakertrans Muchtar Luthfi Membuka Forum Inkubator Bisnis Asia Pasific di Bandung. Retrieved from http://arcom.co.id/2013/06/11/sekjen-kemenakertrans-muchtar-luthfi-membuka -forum-inkubator-bisnis-asia-pasific-di-bandung/

Astuti, D. A. W. (2009). Pengaruh Konteks Keluarga, Kerja, Pendidikan, Hambatan Dalam Memulai Bisnis, Dukungan Sosial, Nilai - Nilai Individualisme dan Kolektivisme Pada Intensi Berwirausaha.

Astuti, P. F. (2013). Pengaruh Prestasi Belajar Mata Pelajaran Kewirausahaan Terhadapa Minat Berwirusaha Siswa.

Bandura, A. (1977). Self Efficacy: Toward a Unifying theory of Behavioral Change. Psychologicall Review, 84(2), 191-215. http://dx.doi.org/10.1037/0033-295X.84.2.191

Baron, R. A. (2006). Opportunity Recognition as Pattern Recognition: How Entrepreneurs "Connect the Dots" to Identify New Business Opportunities. Academy of Management Perspectives, 20(1), 104-120. http://dx.doi.org/10.5465/AMP.2006.19873412 
Brawijaya University. (2013). Mengapa Mahasiswa Harus Berwirausaha? Retrieved December 11, 2013, from http://palupimanajemen.lecture.ub.ac.id/2013/02/mengapa-mahasiswa-harus-berwirausaha/

Carter, N. M., Gartner, W. B., \& Greene, P. G. (2002). The Career Reasons Of Minority Nascent Entrepreneurs. Academy of Management Proceedings, 2002(1), D1-D6. http://dx.doi.org/10.5465/APBPP.2002.7516614

Choo, S., \& Wong, M. (2006). Entrepreneurial Intention: Triggers and Barriers to New Venture Creations in Singapore. Singapore Management Review, 28(2), 47-65.

Cole, A. H. (1959). Business Enterprise in Its Social Setting. Cambridege, MA: Harvard University Press.

Custer, R. L., Scarcella, J. A., \& Stewart, B. R. (1999). The modified Delphi technique: A rotational modification. Journal of Vocational and Technical Education, 15(2), 1-10.

Dalkey, N. C. (1972). The Delphi method: An experimental study of group opinion. In N. C. Dalkey, D. L. Rourke, R. Lewis, \& D. Snyder (Eds.), Studies in the quality of life: Delphi and decision-making (pp. 13-54). Lexington, MA: Lexington Books.

Dodd, S. D., Komselis, A., \& Hassid, J. (2009). The comparative perceived desirability and feasibility of entrepreneurship within. Spoudai, 59(1), 38-56.

Fishbein, M., \& Ajzen, I. (1975). Belief, Attitude, Intention, and Behavior: An Introduction to Theory and Research. Reading, Mass. : Addison-Wesley Pub. Co.

Fitriati, R. (2012). Entrepreneurship Education: Toward Models In Several Indonesia University. In Prosiding the 4th International Conference on Indonesian Studies: Unity, Diversity and Future (pp. 681-698).

Gasse, Y., \& Tremblay, M. (2011). Entrepreneurial Beliefs and Intentions: A Cross-Cultural Study of University Students in Seven Countries. International Journal of Business, 16(4), 304-314.

Giagtzi, Z. (2013). How Perceived Feasibility and Desirability of Entrepreneurship Influence Entrepreneurial Intentions: A comparison Between Southern and Northern European Countries. Erasmus Universiteit Rotterdam, Erasmus School of Economic.

Guerrero, M., Rialp, J., \& Urbano, D. (2006). The impact of desirability and feasibility on entrepreneurial intentions: A structural equation model. International Entrepreneurship and Management Journal, 4(1), 35-50. http://dx.doi.org/10.1007/s11365-006-0032-x.

Gundry, L. K., \& Kickul, J. R. (2007). Entrepreneurship Strategy: Changing Patterns in New Venture Creation, Growth, and Reinvention (p. 424). New York: SAGE Publications, Inc.

Gurbuz, G., \& Aykol, S. (2008). Enterepreneurial Intention Of Young Educated Public In Turkey. Journal of Global Strategic Management, 4, 47-56.

Haynie, J. M., Shepherd, D. a., \& McMullen, J. S. (2009). An Opportunity for Me? The Role of Resources in Opportunity Evaluation Decisions. Journal of Management Studies, 46(3), 337-361. http://dx.doi.org/10.1111/j.1467-6486.2009.00824.x

Hisrich, R. D., \& Peters, M. P. (1998). Entrepreneurship (p. 681). McGraw-Hill.

Hyrsky, K., \& Tuunanen, M. (1999). Innovativeness and Risk-taking Propensity: A Cross-Cultural Study of Finnish and U. S. Entrepreneurs and Small Business Owner. Retrieved December 23, 2013, from http://ta.hse.fi/1999/3/lta_1999_03_a2.pdf

Ifham, A., \& Helmi, A. F. (2002). Hubungan Kecerdasan Emosi Dengan Kewirausahaan Pada Mahasiswa.

Kao, R. (1995). Entrepreneurship: A wealth Creation and Value-Adding Process. Singapore: Prentice-Hall.

Knight, F. H. (1921). Risk, Uncertainty and Profit. New York: Harper and Row.

Krueger, N. (1993). The Impact of Prior Entrepreneurial Exposure on Perceptions of New Venture Eeasibility and Desirability. Entrepreneurship Theory and Practice, 18(1), 5-21.

Krueger, N., Reilly, M. D., \& Carsrud, A. L. (2000). Competing models of entrepreneurial intentions. Journal of Business Venturing, 15(5-6), 411-432. http://dx.doi.org/10.1016/S0883-9026(98)00033-0

Kuehn, K. W. (2008). Entrepreneurial Intentions Research: Implications For Entrepreneurship Education. Journal of Entrepreneurship Education, 11(1).

Kumar, D. K. (2013). Ways and Means of Research Method (1st ed.). New Delhi: Research India Publications. 
Lee, S. H., \& Wong, P. K. (2004). An exploratory study of technopreneurial intentions: A career anchor perspective. Journal of Business Venturing, 19(1), 7-28. http://dx.doi.org/10.1016/S0883-9026(02)00112-X

León, J. A. M., Descals, F. J. P., \& Domínguez, J. F. M. (2007). The Psychosocial Profile of The University Entrepreneur. Journal of Psychology in Spain. Retrieved December 11, 2013, from http://www.academia.edu/229127/The_Psychosocial_Profile_Of_The_University_Entrepreneur

Lestari, R. B., \& Wijaya, T. (2012). Pengaruh Pendidikan Kewirausahaan Terhadap Minat Berwirausaha Mahasiswa di STIE MDP, STMIK MDP, dan STIE MUSI. Jurnal Ilmiah STIE MDP, 1(2), 112-119. Retrieved from http://eprints.mdp.ac.id/672/1/6.Pengaruh Pendidikan Kewirausahaan Terhadap Minat Berwirausaha Mahasiswa di STIE MDP, STMIK MDP, dan STIE MUSI .pdf

McMullen, J. S., \& Shepherd, D. a. (2006). Entrepreneurial Action and the Role of Uncertainty in the Theory of the Entrepreneur. Academy of Management Review, 31(1), 132-152.

Mcstay, D. (2008). An investigation of undergraduate student self-employment intention and the impact of entrepreneurship education and previous entrepreneurial experience. Presented By. Bond University.

Mitchell, R. K., Busenitz, L. W., Lant, T., Mcdougall, P. P., Morse, E. A., \& Smith, J. B. (2002). Toward a Theory of Entrepreneurial Cognition: Rethingking the People Side of Entrepreneurship Research. Entrepreneurship theory and Practice, 93-104. http://dx.doi.org/10.1111/1540-8520.00001

Mulyana, R. A. (2013). Pengaruh Norma Subyektif, Persepsi Kontrol Perilaku, Dan Sikap Wirausaha Terhadap Minat Berwirausaha Siswa Smk. Universitas Pendidikan Indonesia.

Mustikawati, I., \& Bachtiar, M. (2008). Hubungan Antara Dukungan Sosial (Orang Tua) Dengan Minat Berwirausaha Pada Siswa Sekolah Menengah Kejuruan Oleh: Fakultas Psikologi Dan Ilmu Sosial Budaya Universitas Islam Indonesia Yogyakarta. Yogyakarta.

Pfeiffer, J. (1968). New look at education. Poughkeepsie, NY: Odyssey Press.

Putra, R. A. (2012). Faktor-Faktor Penentu Minat Mahasiswa Manajemen Untuk Berwirausaha (Studi Mahasiswa Manajemen FE Universitas Negeri Padang). Jurnal Manajemen, 1(1). Retrieved from ejournal.unp.ac.id/students/index.php/mnj/article/download/45/33

Rahmawati, P., Suwarto, D. H., \& Endarwati, M. L. (2010). Technopreneurship Course Development Program.

Ramadhan, A. (2012). Politik Ekonomi Generasi Muda Implementasi kebijakan Gerakan Kewirausahaan Nasional di Jawa Timur. Jurnal Politik Muda, 2(1), 1-8.

Rochmah, S. (2013). Perpres 27 Tahun 2013: Mendukung UMKM Sambut Masyarakat Ekonomi ASEAN 2015. Sekretariat Kabinet Republik Indonesia. Retrieved from http://www.setkab.go.id/mobile/artikel-8679perpres-27-tahun-2013-mendukung-umkm-sambut-masyarakat-ekonomi-asean-2015.html

Schumpeter, J. A. (1934). The Theory of Economic Development: An Inquiry Into Profits, Capital, Credit, Interest, and the Business Cycle. Cambridge MA: Harvard University Press.

Sexton, D. L., \& Bowman-Upton, N. B. (1991). Entrepreneurship; Creative Ability in Business; Venture Capital. Macmillan (New York).

Shapero, A., \& Sokol, L. (1982). The Social Dimensions of Entrepreneurship. In Encyclopedia of Entrepreneurship. Retrieved from http://ssrn.com/abstract=1497759

Sulistyorini, U. T. (2013). Metode pembelajaran kewirausahaan dalam membangun perilaku kewirausahaan. Jurnal Administrasi dan Bisnis, 4(1). Retrieved from http://admisibisnis.blogspot.com/2013/07/metodepembelajaran-kewirausahaan-dalam.html

Sutarto. (2012). Minat Wirausaha Mahasiswa Masih Rendah. Lensaindonesia. Retrieved December 12, 2013, from http://www.lensaindonesia.com

Zain, M. (2013). Makin Tinggi Tingkat Pendidikan, Semakin Rendah Minat Kewirausahaannya. Antaranews.com. Retrieved December 12, 2013, from http://www.antaranews.com/print/109998/

\section{Copyrights}

Copyright for this article is retained by the author(s), with first publication rights granted to the journal.

This is an open-access article distributed under the terms and conditions of the Creative Commons Attribution license (http://creativecommons.org/licenses/by/3.0/). 